\title{
FORMULATION AND EVALUATION OF GEL MASK PEEL OF BLACK GLUTINOUS RICE EXTRACT (ORYZA SATIVA VAR GLUTINOSA) AND GREEN TEA (CAMELIA SINENSIS)
}

\author{
Ajeng Ayu Pebriani ${ }^{1 *}$, Maya Uzia Beandrade ${ }^{2}$ \\ 1. Department of Pharmacy, STIKes Mitra Keluarga, Bekasi-Indonesia. \\ 2. Department of Pharmacy, STIKes Mitra Keluarga, Bekasi-Indonesia.
}

*Correspondence: Ajeng Ayu Pebriani | STIKes Mitra Keluarga | ajengayupebriany@gmail.com

\begin{abstract}
Introduction: Black glutinous rice (Oriza sativa var glutinosa) and green tea (Camelia sinensis) are plants that are useful for moisturizing the skin. The purpose of this study was to obtain the best formulation of peel-off gel mask preparations from black glutinous rice and green tea extract.

Method: The gel mask formulation was made on the basis of variations in the concentration of Hydroxy Propyl Methyl Cellulose (HPMC) of F1 (2,5\%), F2 (3\%) and F3 (3,5\%) with evaluation including organoleptic tests, pH, viscosity, homogenity, dispersity test, and drying time at temperatures of $4{ }^{\circ} \mathrm{C}, 25^{\circ} \mathrm{C}, 40^{\circ} \mathrm{C}$ for 28 days.

Results: The evaluation results of the three formulations met the requirements for a good peel-off gel mask. $\mathrm{pH}$ results are between 4.6-5.5 which is still in the standard range of 4.5-6.0. The results of the viscosity test are 6.50012.166.7 cps which are in the range of $6.000-24.000 \mathrm{cps}$, the dispersion area meets the requirements of $5-7 \mathrm{~cm}$, the result of the drying time is 15-22 minutes which are in the range of 15-30 minutes.

Conclusion: The conclusion of this study was that F1, F2, and F3 met all the requirements for peel off gel masks by storing at temperatures of $4^{\circ} \mathrm{C}, 25^{\circ} \mathrm{C}, 40^{\circ} \mathrm{C}$ for 28 days.
\end{abstract}

Keywords: peel-off mask, black glutinous rice extract, green tea extract, HPMC, stability test.

Received October 19, 2021; Accepted December 30, 2021

\section{INTRODUCTION}

Currently, the use of natural ingredients that are safer for the skin has been developed as a source of antioxidants in cosmetic preparations. Antioxidants are compounds that are useful for neutralizing the increase in free radicals, protecting cells from the resulting toxic effects and can also contribute to the prevention of diseases. Antioxidants are found in many plants. One of them is black glutinous rice (Oryza sativa var glutinosa). Black glutinous rice is one type of rice that contains secondary metabolites such as alkaloids, flavonoids, tannins and steroids (Iryani et al., 2017). Black glutinous rice contains anthocyanin pigments. Anthocyanins are pigments from the flavonoid group that are soluble in water, have a red to blue color and are widely distributed in plants. (Rantika et al., 2019). In addition to black glutinous rice, another natural active ingredient that contains antioxidants is green tea. The composition of tea leaves is known to be very complex. More than 400 chemical components have been identified in tea leaves. The amount of this chemical component varies depending on the soil, climate, and the age of the tea leaves when picked. Catechins (polyphenols) are powerful antioxidants, stronger than vitamins $\mathrm{E}, \mathrm{C}$ and -carotene (Habiburrohman Denny and Sukohar Asep, 2018). The main content of catechins (polyphenols) in green tea, especially epicatechin (EC), epigallocatechin (EGC), epicatechin galatte (ECG) and EGC gallate have proven to be used as antioxidants (Fajar et al., 2018). Antioxidants can produce a better effect when formulated in topical dosage forms on the face because the active substances can interact longer on the face. One of the topical dosage forms that has been widely developed is the peel-off mask. Peel-off gel mask is an alternative preparation that can increase the comfort of use and is expected to increase the antioxidant activity of black glutinous rice and green tea with the effect of using a peel-off gel mask base, namely Polyvinyl Alcohol (PVA) (Muflihunna et al., 2019). PVA is a very important ingredient in the formulation of peel-off mask preparations, because PVA plays a role in providing a peel-off effect because it has adhesive properties so that it can form a film that is easy to peel off after drying. Based on the results of research that has been carried out, the concentration of PVA which is used as a film-forming layer for a peel-off gel facial mask can be used with PVA with a concentration range of 10-16\% having the most 
optimal pharmaceutical stability (Sulastri and Chaerunisaa, 2018).

From several studies that have been carried out, I want to make a combination formulation of black glutinous rice and green tea which is currently still rarely developed in the form of a peel-off mask. Research on the preparation of a peel-off gel mask from green tea leaf extract (Camellia sinensis) and rice Black sticky rice (Oryza Sativa var Glutinosa) with various HPMC base concentrations of 2.5\%, 3\%, 3.5\% was developed into cosmetic preparations used topically by the public.

\section{METHOD}

\section{Peel off mask optimization}

Tests of several concentrations of additives used for create an optimum peel off mask formula. Optimization is expected to produce formula with maintained stability based on several tests. As for the formula master that have been optimized are:

Table 1. Peel-Off Mask Preparation Formula (Nurwaini and Sari, 2019).

\begin{tabular}{ccccc}
\hline \multirow{2}{*}{ Bahan (\%) } & \multicolumn{3}{c}{ Formula } & Fungsi \\
\cline { 2 - 4 } & I & II & III & \\
\hline Black Glutinous Rice Extract & 4,6 & 4,6 & 4,6 & Skin lightening \\
\hline Green Tea Extract & 0,16 & 0,16 & 0,16 & Skin lightening \\
\hline Polyvinil alcohol & 10 & 10 & 10 & Gelling agent \\
\hline Propylenglikol & 12 & 12 & 12 & Stabilizer \\
\hline HPMC & 2,5 & 3 & 3,5 & Gelling agent \\
\hline Metil Paraben & 0,3 & 0,3 & 0,3 & Pengawet \\
\hline Aqua Destillata ad & 100 & 100 & 100 & Pelarut \\
\hline
\end{tabular}

\section{Preparation of Peel-off Masks}

The materials were weighed, HPMC was developed by adding aquadest at a temperature of $70-80^{\circ} \mathrm{C}$ then stirred until it was clear and homogeneous (mixture I). Polyvinyl alcohol was added with distilled water at room temperature, then heated on a water bath at $80^{\circ} \mathrm{C}$ until it swelled completely, then cooled. Then homogenize using a homogenizer (mixture II). Then enter Mixture I into Mixture II) little by little, homogenize using a homogenizer until a base becomes a gel (mixture III). Propylene glycol and methyl paraben were mixed until homogeneous (mixture IV). Mix III is put into mixture IV and add black glutinous rice extract and green tea extract. All materials were homogenized using a homogenizer at the optimum speed and time. The preparation was left for 48 hours to remove the foam. An evaluation of the formulation was carried out (Kindangen et al., 2018).

\section{Stability Testing of Physical Properties of Peel-Off Gel Mask Preparations}

1. Organoleptic observations

Organoleptic testing was carried out by observing changes in shape, color, and odor of the gel mask preparation. Tests were carried out at storage temperatures of $4^{\circ} \mathrm{C}, 25^{\circ} \mathrm{C}, 40^{\circ} \mathrm{C}$ on days $0,7,14,21,28$ (Muflihunna et al., 2019).

2. $\mathrm{pH}$ testing

3. Measurement of the $\mathrm{pH}$ of the preparation was carried out using a $\mathrm{pH}$ meter. The $\mathrm{pH}$ of the mask preparation must be in accordance with the $\mathrm{pH}$ of the skin, which is 4.5-6.5. A number of peel-off mask gels are inserted into the $\mathrm{pH}$ meter. Tests were carried out at storage temperatures of $4^{0} \mathrm{C}, 25^{\circ} \mathrm{C}$, $40^{\circ} \mathrm{C}$ on days $0,7,14,21,28$ (Wulansari et al., 2020).

4. Viscosity Test

Viscosity determination was carried out using a Brookfield type LV viscometer. A total of $250 \mathrm{ml}$ of gel was put into a $250 \mathrm{ml}$ beaker glass then put the spindle immersed in the preparation. Then the spindle speed is set successively $0,5,2,5,10,20 \mathrm{rpm}$ then reversed $20,10,5,2,0,5$ the scale is read when the moving red needle has stabilized. Tests were carried out at storage temperatures of 40C, 
250C, 400C on days $0,7,14,21,28$. The viscosity value of a good peel-off gel mask preparation is 3000-50,000 cps (Rantika et al., 2019).

5. Homogeneity Test

The homogeneity test is carried out by placing the preparation on a slide, then seeing whether there are coarse particles or inhomogeneities. Tests were carried out at storage temperatures of $4^{\circ} \mathrm{C}, 25^{\circ} \mathrm{C}, 40^{\circ} \mathrm{C}$ on days $0,7,14,21,28$ (Santoso et al., 2020).

6. Drying Preparation Time Test

1 gram of peel-off mask gel is applied to the skin of the arm with a length of $7 \mathrm{~cm}$ and a width of $7 \mathrm{~cm}$. Then the speed of drying the gel was calculated to form a film layer of the peel-off mask gel using a stopwatch. Tests were carried out at storage temperatures of $4^{0} \mathrm{C}, 25^{\circ} \mathrm{C}, 40^{\circ} \mathrm{C}$ on days $0,7,14,21,28$. A good drying time for peel-off gel mask preparations is 15-30 minutes (Zubaydah and Fandinata, 2020).

\section{RESULTS}

Stability Test Results of Physical Properties Peel-Off gel mask

Stability test of the physical properties of peel-off masks was carried out at temperatures of $40 \mathrm{C}$, 250C, 400C on days $0,7,14,21$ and 28 which included organoleptic examination, pH, viscosity, homogeneity, spreadability and drying time.

\section{Results of Organoleptic Observations of Peel-Off Masks}

Table 1. Organoleptic Test Results Observation Table

\begin{tabular}{|c|c|c|c|c|c|c|}
\hline \multirow{3}{*}{ Formulation } & \multirow{3}{*}{ Criteria } & \multicolumn{5}{|c|}{ Organoleptik Test } \\
\hline & & \multicolumn{5}{|c|}{ Temperatures $4^{0} \mathrm{C}$} \\
\hline & & Day-0 & Day-7 & Day-14 & Day-21 & Day-28 \\
\hline F1 & Odor & Odorless & Odorless & Odorless & Odorless & Odorless \\
\hline F2 & Color & Brown & Brown & Brown & Brown & Brown \\
\hline F3 & Homogenity & Homogen & Homogen & Homogen & Homogen & Homogen \\
\hline \multicolumn{7}{|c|}{ Temperatures $25^{\circ} \mathrm{C}$} \\
\hline F1 & Odor & Odorless & Odorless & Odorless & Odorless & Odorless \\
\hline $\mathbf{F} 2$ & Color & Brown & Brown & Brown & Brown & Brown \\
\hline $\mathbf{F 3}$ & Homogenity & Homogen & Homogen & Homogen & Homogen & Homogen \\
\hline \multicolumn{7}{|c|}{ Temperatures $40^{\circ} \mathrm{C}$} \\
\hline F1 & Odor & Odorless & Odorless & Odorless & Odorless & Odorless \\
\hline $\mathbf{F} 2$ & Color & Brown & Brown & Brown & Brown & Brown \\
\hline F3 & Homogenity & Homogen & Homogen & Homogen & Homogen & Homogen \\
\hline
\end{tabular}

\section{Information:}

F1 : Peel-off mask with 2,5\% HPMC concentration

F2 : Peel-off mask with $3 \%$ HPMC concentration

F3 : Peel-off mask with 3,5\% HPMC concentration 


\section{Peel-Off Mask pH Test Results}

Table 2. Observation Table of $\mathrm{pH}$ Test Results

\begin{tabular}{cccccc}
\hline \multirow{2}{*}{ Formulation } & \multicolumn{5}{c}{ pH Test Temperature 40 $\mathbf{0}^{\mathbf{C}}$} \\
\cline { 2 - 6 } & Day-0 & Day-7 & Day-14 & Day-21 & Day-28 \\
\hline F1 & $4,9 \pm 0,06$ & $4,8 \pm 0,06$ & $4,7 \pm 0,10$ & $4,8 \pm 0,06$ & $4,6 \pm 0,06$ \\
F2 & $5,3 \pm 0,06$ & $5,0 \pm 0,21$ & $4,9 \pm 0,06$ & $4,8 \pm 0,10$ & $4,7 \pm 0,06$ \\
F3 & $4,8 \pm 0,06$ & $4,6 \pm 0,06$ & $4,7 \pm 0,10$ & $4,7 \pm 0,10$ & $4,7 \pm 0,06$ \\
\hline & pH Test Temperature 250 C \\
F1 & $5,1 \pm 0,06$ & $5,2 \pm 0,06$ & $4,9 \pm 0,06$ & $4,9 \pm 0,06$ & $4,8 \pm 0,10$ \\
F3 & $5,4 \pm 0,06$ & $5,4 \pm 0,06$ & $5,3 \pm 0,06$ & $5,2 \pm 0,10$ & $5.0 \pm 0,06$ \\
& $4,8 \pm 0,10$ & $4,8 \pm 0,06$ & $4,8 \pm 0,06$ & $4,7 \pm 0,10$ & $4,7 \pm 0,06$ \\
\hline F1 & $5,2 \pm 0,06$ & pH Test Temperature 40 C & \\
F2 & $5,5 \pm 0,06$ & $5,4 \pm 0,06$ & $5,4 \pm 0,06$ & $5,4 \pm 0,06$ & $5,3 \pm 0,06$ \\
F3 & $4,7 \pm 0,10$ & $4,6 \pm 0,06$ & $4,7 \pm 0,10$ & $4,8 \pm 0,10$ & $4,8 \pm 0,06$ \\
\hline
\end{tabular}

\footnotetext{
Information:

F1 : Peel-off mask with 2,5\% HPMC concentration

F2 : Peel-off mask with $3 \%$ HPMC concentration

F3 : Peel-off mask with 3,5\% HPMC concentration
}

\section{Peel-Off Mask Viscosity Test Results}

Table 3. Viscosity Test Results Observation Table

\begin{tabular}{|c|c|c|c|c|c|}
\hline \multirow{2}{*}{ Formulation } & \multicolumn{5}{|c|}{ Viscosity Test Temperature $4^{0} \mathrm{C}$} \\
\hline & Day-0 & Day-7 & Day-14 & Day-21 & Day-28 \\
\hline F1 & $9166,7 \pm 235,7$ & $11166,7 \pm 235,7$ & $13166,7 \pm 577,4$ & $12833,3 \pm 288,7$ & $14166,7 \pm 288,7$ \\
\hline F2 & $9166,7 \pm 288,7$ & $12666,7 \pm 577,4$ & $12833,3 \pm 763,8$ & $13000,0 \pm 500,0$ & $13333,3 \pm 763,8$ \\
\hline F3 & $9166,7 \pm 577,4$ & $11166,7 \pm 288,7$ & $12833,3 \pm 577,4$ & $12833,3 \pm 577,4$ & $13000,0 \pm 500,0$ \\
\hline \multicolumn{6}{|c|}{ Viscosity Test Temperature $25^{\circ} \mathrm{C}$} \\
\hline F1 & $9166,7 \pm 235,7$ & $10333,3 \pm 235,7$ & $10166,7 \pm 235,7$ & $10000,0 \pm 408,2$ & $9000,0 \pm 408,2$ \\
\hline F2 & $9166,7 \pm 288,7$ & $11166,7 \pm 288,7$ & $10333,3 \pm 763,8$ & $10333,3 \pm 288,7$ & $7833,3 \pm 288,7$ \\
\hline F3 & $9166,7 \pm 577,4$ & $8833,3 \pm 763,8$ & $900,0 \pm 500,0$ & $9666,7 \pm 288,7$ & $12166,7 \pm 288,7$ \\
\hline \multicolumn{6}{|c|}{ Viscosity Test Temperature $40^{\circ} \mathrm{C}$} \\
\hline F1 & $9166,7 \pm 235,7$ & $9166,7 \pm 235,7$ & $8833,3 \pm 288,7$ & $7333,3 \pm 235,7$ & $6500,0 \pm 408,2$ \\
\hline F2 & $8833,3 \pm 288,7$ & $8833,3 \pm 288,7$ & $8833,3 \pm 288,7$ & $6666,7 \pm 288,7$ & $7500,0 \pm 500,0$ \\
\hline $\mathbf{F 3}$ & $9166,7 \pm 577,4$ & $10000,0 \pm 500,0$ & $7666,7 \pm 288,7$ & $7500,0 \pm 500,0$ & $7000,0 \pm 500,0$ \\
\hline
\end{tabular}

\section{Information:}

F1 : Peel-off mask with 2,5\% HPMC concentration

F2 : Peel-off mask with $3 \%$ HPMC concentration

F3 : Peel-off mask with 3,5\% HPMC concentration 
Result of Peel-Off Mask Homogenity Test

\begin{tabular}{|c|c|c|c|c|c|c|}
\hline \multirow{2}{*}{ Formulation } & \multicolumn{2}{|c|}{ Temperature $4^{0} \mathrm{C}$} & \multicolumn{2}{|c|}{ Temperature $25^{\circ} \mathrm{C}$} & \multicolumn{2}{|c|}{ Temperature $40^{\circ} \mathrm{C}$} \\
\hline & Day-0 & Day-28 & Day-0 & Day-28 & Day-0 & Day-28 \\
\hline 1 & & & & & & \\
\hline 2 & & & & & & \\
\hline 3 & & & & & & \\
\hline
\end{tabular}

Figure 1. Homogeneity Test Result

Information:

F1 : Peel-off mask with 2,5\% HPMC concentration

F2 : Peel-off mask with $3 \%$ HPMC concentration

F3 : Peel-off mask with 3,5\% HPMC concentration

Test Results of Peel-Off Mask Spreadability

Table 4. Observation Table of 40C . Temperature Spreadability Test Results SPREAD POWER TEST (cm)

\begin{tabular}{ccccc}
\hline \multirow{2}{*}{ Day to- } & \multirow{2}{*}{ Formulation } & \multicolumn{3}{c}{ Temperature Observation $\mathbf{4}^{\mathbf{0}} \mathbf{C}$} \\
& & $\mathbf{5 0}$ & $\mathbf{1 0 0}$ & $\mathbf{2 0 0}$ \\
\hline \multirow{3}{*}{0} & F1 & $5,2 \pm 0,1$ & $5,4 \pm 0,1$ & $5,8 \pm 0,1$ \\
& F2 & $5,2 \pm 0,1$ & $5,4 \pm 0,1$ & $5,7 \pm 0,1$ \\
& F3 & $5,2 \pm 0,1$ & $5,3 \pm 0,1$ & $5,6 \pm 0,1$ \\
\hline \multirow{2}{*}{7} & F1 & $5,2 \pm 0,1$ & $5,4 \pm 0,1$ & $5,7 \pm 0,1$ \\
& F2 & $5,1 \pm 0,1$ & $5,3 \pm 0,1$ & $5,6 \pm 0,1$ \\
& F3 & $5,1 \pm 0,1$ & $5,4 \pm 0,1$ & $5,7 \pm 0,1$ \\
\hline \multirow{3}{*}{14} & F1 & $5,0 \pm 0,1$ & $5,3 \pm 0,1$ & $5,8 \pm 0,1$ \\
& F2 & $5,0 \pm 0,1$ & $5,3 \pm 0,1$ & $5,6 \pm 0,1$ \\
& F3 & $5,2 \pm 0,1$ & $5,6 \pm 0,1$ & $5,8 \pm 0,1$ \\
\hline \multirow{2}{*}{21} & F1 & $5,1 \pm 0,1$ & $5,4 \pm 0,1$ & $5,8 \pm 0,1$ \\
& F2 & $5,2 \pm 0,1$ & $5,4 \pm 0,1$ & $5,9 \pm 0,1$ \\
& F3 & $5,1 \pm 0,1$ & $5,4 \pm 0,1$ & $5,8 \pm 0,1$ \\
\hline \multirow{2}{*}{28} & F1 & $5,1 \pm 0,1$ & $5,3 \pm 0,1$ & $5,8 \pm 0,1$ \\
& F2 & $5,1 \pm 0,1$ & $5,3 \pm 0,1$ & $5,7 \pm 0,1$ \\
& F3 & $5,0 \pm 0,1$ & $5,3 \pm 0,1$ & $5,8 \pm 0,1$ \\
\hline
\end{tabular}

\section{Information:}

F1 : Peel-off mask with 2,5\% HPMC concentration

F2 : Peel-off mask with 3\% HPMC concentration

F3 : Peel-off mask with 3,5\% HPMC concentration 
Test Result of Peel-Off Mask Drying Time

Table 5. Observation Table of Drying Time Test Results

\begin{tabular}{cccccc}
\hline \multirow{2}{*}{ Formulation } & \multicolumn{5}{c}{ Dry Time Test (minutes,seconds) } \\
\cline { 2 - 6 } & Day-0 & Day-7 & Day-14 & Day-21 & Day-28 \\
\hline \multicolumn{7}{c}{ Temperature $\mathbf{4 0}^{\mathbf{0}} \mathbf{C}$} \\
\hline F1 & $15,35 \pm 0,08$ & $15,56 \pm 1,48$ & $16,22 \pm 0,80$ & $19,02 \pm 1,09$ & $20,58 \pm 2,58$ \\
F2 & $16,41 \pm 0,62$ & $17,20 \pm 1,93$ & $18,26 \pm 3,26$ & $19,39 \pm 0,60$ & $21,26 \pm 1,88$ \\
F3 & $20,16 \pm 1,75$ & $16,22 \pm 0,09$ & $19,46 \pm 0,51$ & $20,19 \pm 0,99$ & $21,52 \pm 0,57$ \\
\hline \multicolumn{7}{c}{ Temperature $\mathbf{2 5}^{\mathbf{0}} \mathbf{C}$} \\
\hline F1 & $15,35 \pm 0,08$ & $15,21 \pm 1,00$ & $16,20 \pm 0,92$ & $15,19 \pm 0,97$ & $18,52 \pm 2,53$ \\
F2 & $16,41 \pm 0,62$ & $19,21 \pm 1,99$ & $17,22 \pm 1,76$ & $19,22 \pm 1,06$ & $21,19 \pm 0,06$ \\
F3 & $20,16 \pm 1,75$ & $17,82 \pm 1,53$ & $21,21 \pm 0,94$ & $20,94 \pm 0,51$ & $16,51 \pm 1,48$ \\
\hline \multicolumn{7}{c}{ Temperature $\mathbf{4}^{\mathbf{0}} \mathbf{C}$} \\
\hline F1 & $15,35 \pm 0,08$ & $15,21 \pm 1,00$ & $16,51 \pm 1,11$ & $18,52 \pm 0,64$ & $18,54 \pm 1,54$ \\
F2 & $16,41 \pm 0,62$ & $18,45 \pm 1,16$ & $19,20 \pm 2,06$ & $21,51 \pm 1,52$ & $22,06 \pm 0,06$ \\
F3 & $20,16 \pm 1,75$ & $17,50 \pm 1,53$ & $19,52 \pm 0,62$ & $19,15 \pm 0,01$ & $19,13 \pm 0,12$ \\
\hline \multicolumn{7}{c}{}
\end{tabular}

Information:

F1 : Peel-off mask with 2,5\% HPMC concentration

F2 : Peel-off mask with 3\% HPMC concentration

F3 : Peel-off mask with 3,5\% HPMC concentration

\section{DISCUSSION}

This study aims to determine the physical stability of peel-off gel masks from extracts of black glutinous rice (Oryza sativa var. glutinosa) and green tea (Camelia sinensis) with various HPMC concentrations of $2.5 \%, 3 \%$ and $3.5 \%$ stored at $40 \mathrm{C}, 250 \mathrm{C}$ and $400 \mathrm{C}$ for 28 days. This variation was carried out to optimize the concentration of an effective base to meet the criteria for the physical properties of pharmaceutical peel off masks and to survive in shelf life through stability testing.

The tests based on physical parameters include organoleptic examination, homogeneity, viscosity measurement, $\mathrm{pH}$ measurement, dispersion and drying time. The organoleptic test aims to observe the shape, color and odor of the peel-off mask preparation. Based on the results of the organoleptic evaluation of the peel-off mask preparations of black glutinous rice extract and green tea after being stored for 28 days at $40 \mathrm{C}, 250 \mathrm{C}$ and $400 \mathrm{C}$, it showed that the three formulas were brown in color resulting from the addition of black glutinous rice extract (Oryza sativa var. glutinosa). ) and green tea (Camellia sinensis L.) then for the color, odor and texture of each formula did not change from the beginning of manufacture to the storage limit and had a characteristic green tea odor that was consistent from the beginning of manufacture until the storage time limit. The resulting product is organoleptically stable (Muflihunna et al., 2019). It is important to measure $\mathrm{pH}$ to ensure that the $\mathrm{pH}$ of the preparation is in accordance with the $\mathrm{pH}$ of the skin, so that irritation can be avoided. Peel-off masks are preparations that are applied to facial skin so that the $\mathrm{pH}$ value of the preparation must match the $\mathrm{pH}$ of the facial skin, which is 4.5-6.5. Because if the $\mathrm{pH}$ value of a preparation is too acidic $<4.5$ it will cause skin irritation, whereas if the $\mathrm{pH}$ value of a preparation is $>6.5$ or too alkaline it can cause scaly skin (Kulkarni et al., 2019). The results of the $\mathrm{pH}$ test showed that all formulas had a $\mathrm{pH}$ in the range of 4.5-6.5 for topical preparations. $\mathrm{pH}$ after being stored for 28 days did not change significantly. Stable $\mathrm{pH}$ indicates that the components in the preparation are still in the $\mathrm{pH}$ range category and are not affected by temperature so that the preparation remains stable during storage. So that the results of $\mathrm{pH}$ measurements for formulas based on HPMC were concluded to be stable and safe to use even though they decreased after forced conditions, but the decrease in $\mathrm{pH}$ indicated was very small and still acceptable because it still met the $\mathrm{pH}$ range of preparations for skin.

The viscosity test on the peel-off gel mask preparation aims to determine the effect of the concentration of the active substance on the viscosity of the preparation. The viscosity of the preparation needs to be guaranteed to produce an optimal gel. Gels with too low a viscosity cause contact time with the skin not long enough so that the activity of the active ingredients is not optimal, a large viscosity increases 
retention time at the application site, but also reduces dispersion (Santoso et al., 2020). From the examination of viscosity using a Brookfield Viscometer type LV with spindle 4 at a speed of $12 \mathrm{rpm}$. In general, the viscosity of the three preparations is still in the standard range, which is between $6000-24000$ cps (Hairiyah and Nuryati, 2016). The increase in gel viscosity is influenced by an increase in the concentration of the gelling agent. Increasing the concentration of PVA and HPMC can increase the number of polymer fibers so that more liquid is retained and bound by the gelling agent so that the viscosity of the preparation increases. The increasing concentration of HPMC can increase the viscosity of the peel-off gel mask preparation. (Zubaydah and Fandinata, 2020). While this decrease occurs because the longer the storage time, the longer the preparation is affected by the environment, for example by air. Then the use of less impermeable packaging can also cause the preparation to absorb water from the outside, thereby increasing the volume of water in the preparation (Suryani et al., 2019).

Homogeneity testing aims to observe the presence or absence of coarse particles. Homogeneity is the arrangement of the dispersion phase in the dispersion medium evenly. This is related to the mechanism of action of antioxidants, which function as antioxidants are extracts of black glutinous rice (Oryza sativa var. glutinosa) and green tea (Camellia sinensis L.). Therefore, extracts of black glutinous rice (Oryza sativa var. glutinosa) and green tea (Camellia sinensis L.) must be homogeneously distributed on the mask base so that their effectiveness as antioxidants can be uniform. In terms of homogeneity, at room temperature from the beginning of manufacture until the 28th day the three formulas were homogeneous and did not show any coarse grains when the preparation was smeared on transparent glass. This shows that the composition of the ingredients in the three formulations is dissolved or evenly dispersed (Ningsih et al., 2016). Likewise, at a cold temperature of $4^{0} \mathrm{C}$ and a hot temperature of $40^{\circ} \mathrm{C}$, the three formulas did not show the presence of coarse grains.

The spreadability test is intended to determine the ability to spread the gel when applied to the skin. Dispersion is an important characteristic in formulations because it affects the transfer of the active ingredient to the target area in the right dose, ease of use, the pressure required to get out of the package and acceptance by consumers (Santoso et al., 2020). From the measurement results, these results indicate that the dispersion area meets the requirements of 5-7 cm (Setia, 2018). A good peel-off gel mask takes less time to spread and will have a high spreadability value. The greater the spreadability, the better the spread of the mask on the skin area to which the mask is applied. The decrease in dispersion occurs through an increase in the size of the molecular unit because it has absorbed the solvent so that the liquid is retained and increases the resistance to flow and spread (Kindangen et al., 2018).

The drying time test is expected to get a good film formulation to be applied, this is also related to user comfort when using it. If the peel-off gel mask preparation dries quickly, it can be said that the preparation is very good to use because in application it does not take a long time to take effect, whereas if the preparation dries for a long time then the preparation also takes a long time to take effect so that sometimes it causes an unpleasant taste. comfortable to use. The expected drying time of the resulting peel-off gel mask is between 15-30 minutes (Leslie and Gunawan, 2019). The difference in drying speed in each formula is influenced by the amount of water concentration contained in the formula so that the drying speed will be longer. The increase in drying time during the 28-day storage period both at room temperature, hot temperatures and cold temperatures can occur because the longer the storage time, the longer the preparation is affected by the environment, for example air (Rantika et al., 2019).

\section{CONCLUSION}

From the research that has been done, it can be concluded:

1. Black glutinous rice extract and green tea can be formulated as a peel-off gel mask preparation with HPMC bases of $2.5 \%, 3 \%$, and $3.5 \%$

2. The formulation of the peel-off gel mask was concluded to be pharmaceutically stable based on the tests that have been carried out, namely:

a. In the organoleptic test F1, F2, F3 each formula during storage for 28 days at 3 temperatures, namely $4^{\circ} \mathrm{C}, 25^{\circ} \mathrm{C}, 40^{\circ} \mathrm{C}$, there was no change in color, smell and texture, this shows that each formula meets the requirements and the homogeneity test shows the three formulas are homogeneous and there are no coarse grains.

b. In the $\mathrm{pH}$ test $\mathrm{F} 1, \mathrm{~F} 2, \mathrm{~F} 3$ each formula during storage for 28 days at 3 temperatures, namely $4^{0} \mathrm{C}$, 
$25^{\circ} \mathrm{C}, 40^{\circ} \mathrm{C} \mathrm{F} 1=4,9-5,2, \mathrm{~F} 2=5,3-5,5$, at $\mathrm{F} 3=4,6-4,8$ indicates a result that meets the requirements of the $\mathrm{pH}$ range that can be accepted by the skin, namely $\mathrm{pH} 4.5-6.5$.

c. In the F1, F2, F3 viscosity test each formula was stored for 28 days at 3 temperatures, namely $4^{0} \mathrm{C}$, $25^{\circ} \mathrm{C}, 40^{\circ} \mathrm{C}$. In $\mathrm{F} 1$ the preparation has a viscosity of $10000 \mathrm{cps}$, for F2 it is $10333 \mathrm{cps}$, while the viscosity of the $\mathrm{F} 3$ preparation is $12166,7 \mathrm{cps}$. In general, the viscosity of the three preparations is still in the standard range, which is between $6000-24000 \mathrm{cps}$

d. In the F1, F2, F3 dispersion test of each formula during storage for 28 days at 3 temperatures, namely $4^{\circ} \mathrm{C}, 25^{\circ} \mathrm{C}, 40^{\circ} \mathrm{C}$ at $\mathrm{F} 1$ which was $6,3, \mathrm{~F} 2$ was 6.1 and $\mathrm{F} 3$ obtained 6,1 spreadability. the three formulas still enter the standard range of $5-7 \mathrm{~cm}$

e. In the long drying time test F1, F2, F3 each formula was stored for 28 days at 3 temperatures, namely $4^{\circ} \mathrm{C}, 25^{\circ} \mathrm{C}, 40^{\circ} \mathrm{C}$. the length of time for $\mathrm{F} 1$ to dry ranges from $15-18$ minutes, then $\mathrm{F} 2$ 1621 minutes and F3 16-20 this is still in the range of 15-30 minutes.

3. Of the three formulas in Formula 1 with HPMC concentration of $2.5 \%$ gave the best results seen from the results of the dispersion test where the dispersion area in formula 1 was the highest than the other formulas and the drying time test in formula 1 had an average The average drying time is the fastest among other formulas so that it is the most effective preparation in its use.

\section{ACKNOWLEDGEMENT}

The author would like to thank STIKes Mitra Keluarga Bekasi for the support during the author's research.

\section{REFERENCE}

Amelinda E., Widarta, I.W.R. dan Darmayanti, L.P.T.,2018. Pengaruh Waktu Maserasi Terhadap Aktivitas Antioksidan Ekstrak Rimpang Temulawak (Curcuma xanthorriza Roxb.).Jurnal Ilmu dan Teknologi Pangan.ISSN : 2527-8010 (ejournal) Vol. 7, No.4, 165-174.

Atalay, D., and Erge, H.S., 2017. Determination of some physical and chemical properties of white, green and black teas (Camellia sinensis). Gida The Journal Of Food Vol: 42(5): $494-504$ doi: 10.15237/gida.GD17024.

Batubara I., and Prastya M.E.,2020. Potential Use of Indonesian Medicinal Plants for Cosmetic and Oral Health: A Review. Jurnal Kimia Valensi, Vol 6 (1) Hal:120-134.

Aditya, M., dan Ariyanti, P. R. (2016). Manfaat Gambir ( Uncaria gambir Roxb ) sebagai Antioksidan Benefits of Gambir ( Uncaria gambir Roxb ) as Antioxidant. Majority, 5(September), 129-133. http://juke.kedokteran.unila.ac.id/index.php/majority/article/viewFile/1049/844.

Adrianta, K. A. (2016). Identifikasi Senyawa Antosianin Ekstrak Etanol Beras Ketan Hitam ( Oryza sativa L.) sebagai Alternatif Pengobatan DBD. Medicamento, 2(1), 17-22.

Amelinda, E., Widarta, I. W. R., dan Darmayanti, L. P. T. (2018). Pengaruh Waktu Maserasi Terhadap Aktivitas Antioksidan Ekstrak Rimpang Temulawak (Curcuma xanthorriza Roxb.). Jurnal Ilmu Dan Teknologi Pangan (ITEPA), 7(4), 165. https://doi.org/10.24843/itepa.2018.v07.i04.p03

Amperawati, S., Hastuti, P., Pranoto, Y., dan Santoso, U. (2019). Efektifitas Frekuensi Ekstraksi Serta Pengaruh Suhu dan Cahaya Terhadap Antosianin dan Daya Antioksidan Ekstrak Kelopak Rosella (Hibiscus sabdariffa L.). Jurnal Aplikasi Teknologi Pangan, 8(1), 38-45. https://doi.org/10.17728/jatp.3527.

Andarina, R., dan Djauhari, T. (2017). Antioksidan dalam Dermatologi. Jurnal Kedokteran Dan Kesehatan, 4(1), 39-48.

Berawi, K. N., Marini, D., Fisiologi, B., Kedokteran, F., Lampung, U., Dokter, M. P., Kedokteran, F., dan Lampung, U. (2018). Efektivitas Kulit Batang Bakau Minyak ( Rhizopora apiculata) sebagai Antioksidan The Effectiveness Rhizopora apiculata Bark as an Antioxidant. 5, 412-417.

Budiwati, G. A. N., Kriswiyanti, E., dan Astarini, I. A. (2020). Aspek Biologi Dan Hubungan Kekerabatan Padi Lokal (Oryza sativa L.) Di Desa Wongaya Gede Kecamatan Penebel, Kabupaten Tabanan, Bali. $\begin{array}{lllll}\text { Metamorfosa: } \quad \text { Journal } & 277 .\end{array}$ https://doi.org/10.24843/metamorfosa.2019.v06.i02.p20.

Chaeikar, S. S., Falakro, K., Rahimi, M., dan Khiavi, S. J. (2020). The investigation of genetic diversity based on SCoT markers, morphological, and chemical characters in tea (Camellia sinensis L .) clones. 3(2), 269-284. https://doi.org/10.22077/jhpr.2020.2848.1097 
Chaiyasut, C., Sivamaruthi, B. S., Pengkumsri, N., Sirilun, S., Peerajan, S., Chaiyasut, K., dan Kesika, P. (2016). Anthocyanin profile and its antioxidant activity of widely used fruits, vegetables, and flowers in Thailand. Asian Journal of Pharmaceutical and Clinical Research, 9(6), 218-224. https://doi.org/10.22159/ajpcr.2016.v9i6.14245

Dewi Anjarsari, I. R. (2016). Katekin teh Indonesia : prospek dan manfaatnya. Kultivasi, 15(2), 99-106. https://doi.org/10.24198/kltv.v15i2.11871

Dontha, S. (2016). a Review on Antioxidant. Asian Journal of Pharmaceutical and Clinical Research, 9(2), $14-32$.

Eker, M. E., Aaby, K., Budic-Leto, I., Brncic, S. R., El, S. N., Karakaya, S., Simsek, S., Manach, C., Wiczkowski, W., dan De Pascual-Teresa, S. (2020). A review of factors affecting anthocyanin bioavailability: Possible implications for the inter-individual variability. Foods, 9(1), 1-18. https://doi.org/10.3390/foods9010002

Fajar, R. I., Wrasiati, L. P., dan Suhendra, L. (2018). Kandungan Senyawa Flavonoid Dan Aktivitas Antioksidan Ekstrak Teh Hijau Pada Perlakuan Suhu Awal Dan Lama Penyeduhan. Jurnal Rekayasa Dan Manajemen Agroindustri, 6(3), 196. https://doi.org/10.24843/jrma.2018.v06.i03.p02

Giannopoulou, I., Saïs, F., dan Thomopoulos, R. (2015). Linked data annotation and fusion driven by data quality evaluation. Revue Des Nouvelles Technologies de l'Information, E.28, 257-262

Giyatmi, G. (2019). Wisata Teh: Sebuah Studi Kasus Di Pantjoran Tea House. Jurnal Industri Pariwisata, 1(2), 135-147. https://doi.org/10.36441/pariwisata.v1i2.23

Habiburrohman Denny dan Sukohar Asep. (2018). Aktivitas Antioksidan dan Antimikrobial pada Polifenol Teh Hijau. Agromedicine Unila, 5(2), 587-591.

Hairiyah, N., dan Nuryati. (2016). Aplikasi Beras Ketan Hitam ( Oryza sativa var glutinous ) dan Madu Sebagai Bahan Dasar Pembuatan Bodyscrub. Jurnal Teknologi Pertanian Andalas, 24(2), 114-121.

Halla, N., Fernandes, I. P., Heleno, S. A., Costa, P., Boucherit-Otmani, Z., Boucherit, K., Rodrigues, A. E., Ferreira, I. C. F. R., dan Barreiro, M. F. (2018). Cosmetics preservation: A review on present strategies. Molecules, 23(7), 1-41. https://doi.org/10.3390/molecules23071571

Hamawi, M., Setyaningrum, H., dan Etica, D. U. (2020). Karakter Morfologis Kultivar Padi Ketan Lokal Ponorogo. Jurnal Agronomi Indonesia (Indonesian Journal of Agronomy), 47(3), 224-231. https://doi.org/10.24831/jai.v47i3.24568

Honda, C., dan Moriya, S. (2018). Anthocyanin biosynthesis in apple fruit. Horticulture Journal, 87(3), 305-314. https://doi.org/10.2503/hortj.OKD-R01

Iryani, I., Iswendi, I., dan Katrina, I. T. (2017). Uji Aktivitas Anti Diabetes Mellitus Senyawa Metabolit Sekunder Fraksi Air Dari Beras Ketan Hitam (Oryza satival. Var glutinosa) Pada Mencit Putih. Eksakta: Berkala Ilmiah Bidang MIPA, 18(01), 54-60. https://doi.org/10.24036/eksakta/vol18iss01/17.

Itthivadhanapong, P., dan Sangnark, A. (2016). Effects of substitution of black glutinous rice flour for wheat flour on batter and cake properties. International Food Research Journal, 23(3), 1190-1198.

Kindangen, O. C., Yamlean, P. V. Y., dan Wewengkang, D. S. (2018). Formulasi Gel Antijerawat Ekstrak Etanol Daun Kemangi (Ocimum basilicum L.) dan Uji Aktivitasnya Terhadap Bakteri Staphylococcus aureus SECARA in vitro. Pharmacon, 7(3), 283-293. https://doi.org/10.35799/pha.7.2018.20505

Kulkarni, S. V, Gupta, A. K., and Bhawsar, S. (2019). Formulation and Evaluation of Activated Charcoal Peel Off Mask. International Journal of Pharmacy Research \& Technology, 9(2), 44-48. https://doi.org/10.31838/ijprt/09.02.06

Leslie, P. J., dan Gunawan, S. (2019). Daun, Uji fitokimia dan perbandingan efek antioksidan pada teh hijau, teh hitam, dan teh putih (Camellia sinensis) dengan metode DPPH (2, 2-difenil-1- pikrilhidrazil). Tarumanagara Medical Journal, Vol. 1, No(2), 383-388. https://journal.untar.ac.id/index.php/tmj/article/view/3841

Muflihunna, A., Mursyid, dan Mumtihanah, A. (2019). Formulasi Dan Evaluasi Masker Gel Peel-Off Ekstrak Etanol Kulit Buah Apel ( Phyrus mallus L ) Sebagai Antioksidan penuaan . Salah satu sediaan kosmetik untuk menjaha kebersihan dan perawatan kulit wajah off ( Muliyawan 2013 ). Oleh karena itu dikembangkan. Jurnal Kesehatan, November, 35-44. https://doi.org/10.24252/kesehatan.v0i0.11355

Musial, C., Kuban-Jankowska, A., and Gorska-Ponikowska, M. (2020). Beneficial properties of green tea catechins. International Journal of Molecular Sciences, 21(5). https://doi.org/10.3390/ijms21051744 
Nawangsari, D. (2019). Formulasi Sediaan Masker Antioksidan Dari Ekstrak Teh Hijau (Camellia Sinensis). Viva Medika: Jurnal Kesehatan, Kebidanan Dan Keperawatan, 10(2), 109-118. https://doi.org/10.35960/vm.v10i2.451

Nilforoushzadeh, M. A., Amirkhani, M. A., Zarrintaj, P., Salehi Moghaddam, A., Mehrabi, T., Alavi, S., dan Mollapour Sisakht, M. (2018). Skin care and rejuvenation by cosmeceutical facial mask. Journal of Cosmetic Dermatology, 17(5), 693-702. https://doi.org/10.1111/jocd.12730

Ningsih, W., Firmansyah, F., dan Fitri, H. (2016). Formulasi Masker Peel Off dengan Beberapa Konsentrasi Ekstrak Etanol Buah Naga Super Merah (Hylocereus costaricensis (F.A.C Weber) Britton \& Rose). Scientia : Jurnal Farmasi Dan Kesehatan, 6(1), 18. https://doi.org/10.36434/scientia.v6i1.37

Nur, S. (2020). Identifikasi Dan Penentuan Kadar Katekin Dari Seduhan Dan Ektrak Etanol Produk Teh Hijau (Camelia sinensi L) Komersial Secara Spektrofotometri Uv-Visible. Majalah Farmasi Dan Farmakologi, 24(1), 1-4. https://doi.org/10.20956/mff.v24i1.9261

Nursal, F. K., Nining, dan Rahmah, A. S. (2021). Formulation and Development of Grape Seed Oil (Vitis Vinifera L) Emulgel Peel-Off Mask using Gelling Agent Hydroxy Propyl Methyl Cellulose (HPMC). IOP Conference Series: Earth and Environmental Science, 755(1), 012046. https://doi.org/10.1088/1755-1315/755/1/012046.

Oscar, B., dan Sumirah, D. (2019). Pengaruh Grooming Pada Customer Relations Coordinator (CRC) Terhadap Kepuasan Pelanggan di PT Astra international TBK Toyota Sales Operation (Auto2000) Pasteur. Jurnal Bisnis Dan Pemasaran, 9(1), 1-11.

P, M., G, M., HD, C., dan A, G. (2019). Beauty Mask: Market and Environment. Journal of Clinical and Cosmetic Dermatology, 3(2), 1-10. https://doi.org/10.16966/2576-2826.141

Paiva, L., Rego, C., Lima, E., Marcone, M., and Baptista, J. (2021). Comparative analysis of the polyphenols, caffeine, and antioxidant activities of green tea, white tea, and flowers from azorean camellia sinensis varieties affected by different harvested and processing conditions. Antioxidants, 10(2), 1-16. https://doi.org/10.3390/antiox10020183

Parwata, M. O. A. (2016). Bahan Ajar Antioksidan. Kimia Terapan Program Pascasarjana Universitas Udayana, April, 1-54.

Rantika, N., Sriarumtias, F. F., Amalia, N., and Nurhabibah. (2019). Formulation and physical stability test of peel-off gel mask from sticky rice (Oryza sativa L. glutinosa) as antioxidant. Jurnal Ilmiah Farmako Bahari, 10(1), 65-75.

Ridwan, M., Kasman, K., dan Darwis, D. (2017). Pembuatan Lapisan Tipis Berbahan Antosianin Beras Ketan Hitam (Oryza Sativa Glutinosa) Menggunakan Metode Spin Coating. Natural Science: Journal of Science and Technology, 6(1), 29-38. https://doi.org/10.22487/25411969.2017.v6.i1.8077

Ridwanto, R., Lubis, M., Syahputra, R., dan Inriyani, R. (2019). Utilisation of Biopolymer Combination as a Material for Making Gel Peel Off Mask. January 2019. https://doi.org/10.4108/eai.18-10$\underline{2018.2287373}$

Santoso, I., Prayoga, T., Agustina, I., dan Rahayu, W. S. (2020). Formulasi Masker Gel Peel-Off Perasan Lidah Buaya (Aloe vera L.) Dengan Gelling Agent Polivinil Alkohol. Jurnal Riset Kefarmasian Indonesia, 2(1), 17-25. https://doi.org/10.33759/jrki.v2i1.33

Sari, D. I., dan Triyasmono, L. (2017). Rendemen dan Flavonoid Total Ekstrak Etanol Kulit Batang Bangkal (Nauclea subdita) dengan Metode Maserasi Ultrasonikasi. Jurnal Pharmascience, 4(1), 48-53. https://doi.org/10.20527/jps.v4i1.5755

Setia Budi, M. R. (2018). Jurnal Farmasi dan Ilmu Kefarmasian Indonesia Vol. 5 No. 2 Desember 201856. Jurnlal Farmasi Dan Ilmu Kefarmasian Indonesia, 12(2), 56-61.

Simanjuntak, A. Y. M., dan Subagyo, R. (2019). Analisis Hasil Fermentasi Pembuatan Bioetanol Dengan Variasi Waktu Menggunakan Bahan (Singkong, Beras Ketan Hitam Dan Beras Ketan Putih). Scientific Journal of Mechanical Engineering Kinematika, 4(2), 79-90. https://doi.org/10.20527/sjmekinematika.v4i2.119

Sitti Zubaydah, W. O., dan Septi Fandinata, S. (2020). Formulasi Sediaan Masker Gel Peel-Off dari Ekstrak Buah Tomat (Solanum Lycopersicum L.) Beserta Uji Aktivitas Antioksidan. Journal Syifa Sciences and Clinical Research, 2(2), 73-82. https://doi.org/10.37311/jsscr.v2i2.6980. 
Suasana, D., Ayu, W. D., dan Ibrahim, A. (2016). Aktivitas Ekstrak Etanol Beras Ketan Hitam (Oryza Sativa L. Var Glutinosa) terhadap Penurunan Kadar Glukosa Darah Mencit (Mus musculus). Prosiding Seminar Nasional Tumbuhan Obat Indonesia Ke-50, 53(9), 147-155.

Sulastri, A., dan Chaerunisaa, A. Y. (2018). Formulasi Masker Gel Peel Off untuk Perawatan Kulit Wajah. Farmaka, 14(3), 17-26.

Suprio, H. W. (2017). Pemanfaatan Beras Ketan Hitam (Oryza sativa L. Indica) dan Madu sebagai Bahan Dasar Pembuatan Lotion Gel. Media Farmasi, XIII(2), 105-110.

Suryani, N., Mubarika, D. N., dan Komala, I. (2019). Pengembangan dan Evaluasi Stabilitas Formulasi Gel yang Mengandung Etil $\mathrm{p}$-metoksisinamat. Pharmaceutical and Biomedical Sciences Journal, 1(November), 29-36.

Suryati, L., dan Saptarini, N. M. (2016). Formulasi Sampo Ekstrak Daun Teh Hijau (Camellia sinensis var. assamica). Indonesian Journal of Pharmaceutical Science and Technology, 3(2), 66. https://doi.org/10.15416/ijpst.v3i2.8680

Syamsul, E. S., Amanda, N. A., dan Lestari, D. (2020). Perbandingan Ekstrak Lamur Aquilaria malaccensis Dengan Metode Maserasi Dan Refluks. Jurnal Riset Kefarmasian Indonesia, 2(2), 97-104. https://doi.org/10.33759/jrki.v2i2.85

Utami, R. R. (2018). Cocoa Antioxidant: Effect of Fermentation and Roasting on Antioxidant Change (Review). Jurnal Industri Hasil Perkebunan, 13, 75-85. http://ejournal.kemenperin.go.id/bbihp/article/view/4062/3429

Utami, W., Mardawati, E., dan Putri, S. H. (2019). Pengujian aktivitas antioksidan kulit buah naga merah (Hylocereus polyrhizus) sebagai masker gel peel off. Jurnal Industri Pertanian, 2(1), 95-102.

Velasco, M. V., Zague, V., Dario, M., Nishikawa, D., Almeida, M., Trossini, G. H. G., Coelho, A. C. V.,and Baby, A. R. (2016). Characterization and Short-Term clinical study of clay facial mask. Journal of Basic and Applied Pharmaceutical Sciencies, 37(1), 1-6.

Vishnoi, H., Bodla, R., Kant, R., and Bodla, R. B. (2018). Green Tea (Camellia Sinensis) and Its Antioxidant Property: a Review. Article in International Journal of Pharmaceutical Sciences and Research, 9(5), 1723. https://doi.org/10.13040/IJPSR.0975-8232.9(5).1723-36

Wulansari, A., Wahyuningsih, S., Kesehatan, P., dan Mulia, B. (2020). Pengaruh Variasi Hpmc Sediaan Masker Gel Peel-Off Ekstrak Etanol Daun Mangga (Mangifera indica L.) Terhadap Stabilitas Fisik Sediaan. The Effect Of Variation Of Hpmc Availability Of Peel-Off Gel Extract Of Mangga Leaf (Mangifera indica L.) On Physical Sta. IJMS-Indonesian Journal On Medical Science, 7(1), 90-96. http://ejournal.ijmsbm.org/index.php/ijms/article/view/216. 